\section{Japan's modest step forward}

\section{Tokyo}

JAPAN last week took a tiny step towards supporting research in foreign countries. The New Energy and Industrial Technology Development Organization (NEDO), a semi-governmental agency supervised by the Ministry of International Trade and Industry (MITI), announced the award of four grants to international teams of scientists based both in Japan and overseas to carry out research on new materials. The grants are part of a small but growing effort by Japan to contribute to international scientific research.

NEDO, originally established to develop new energy sources following the oil crisis of the $1970 \mathrm{~s}$, was re-organized last year to take over many of MITI's major research and development projects including some budding international programmes (see Nature 333, 4; 1988). Earlier this year NEDO awarded a handful of grants for a 'pilot' Human Frontiers Program - Japan's much talked about programme for international research on the brain and molecular recognition. The conditions for the material science grants

Research teams must be composed of scientists based in two or more countries one of which must be Japan. The grants are worth $¥ 30$ million (about $\$ 210,000$ ) a are very similar to those of Frontiers. year and can be extended up to a maximum of three years.

Last week's four awards go to researchers in Japan, the United States, Britain, Italy, West Germany and Korea. NEDO officials hope to expand their grant programme next year to include research on the global environment, but it is not yet clear if NEDO will be involved in MITI's ambitious plans to boost environmental research in Japan. A decision is expected to be reached by the end of next month, when budget proposals for fiscal year 1990 are to be submitted to the Ministry of Finance.

Apart from the small pilot Frontiers and material research programmes, NEDO is in charge of several new large research projects which, in theory, are also open to foreign researchers and companies. An example is a marine biotechnology project begun last October into which MITI hopes to pour over a hundred million dollars over ten years with a similar amount from private industry (see Nature 333, 4; 1988). Foreign researchers and companies can apply to join the project, but all literature describing it is in Japanese and, according to NEDO officials, as a matter of deliberate policy MITI and NEDO are not advertising such projects in English.

David Swinbanks

\section{West German ban on embryo research}

\section{Munich}

A HARD-fought agreement between conservative Bavarians and the rest of West Germany's governing coalition has finally cleared the way for a government ban on research on human embryos. A draft law banning embryo research was approved by the cabinet this week.

It has been clear since the draft was introduced in April 1986 that West Germany would ban some embryo research, especially if it involved germ-line manipulation, the cloning of human beings or the creation of human-animal chimaeras. But Forschungsgemeinschaft (DFG) and the Max Planck Society (MPS) had objected to a total ban on embryo research and the introduction of criminal penalties for violations (see Nature 333, 791; 1988). Their plea for limited, strictly regulated exceptions to the law where life-saving therapies might emerge from embryo research seems to have fallen on deaf ears.

The law was stalled for a year because of objections by the conservative Bavarian government. The Bonn government had intended to include a paragraph regulating heterologous insemination, artificial insemination with sperm from someone science organizations such as the Deutsche other than the husband. For example, the government wanted to forbid a husband who gave his consent to heterologous insemination from later suing his wife for adultery. But Bavaria had objected to allowing any heterologous insemination at all. In a compromise reached last week, the paragraph on heterologous insemination will be removed entirely from the draft law.

In addition to the restrictions mentioned above, the law will ban all use of totipotent cells for research or diagnostic purposes, the use of diagnostic tests to select for the sex of the embryos, and the creation of more embryos than are directly required for in vitro fertilization procedures. The law also bans surrogate motherhood, effectively forbidden in West Germany since 1987 through the application of adoption laws.

In order to take effect, the law must still pass both houses of the West German Parliament by next year. Despite their earlier stance, DFG and MPS do not plan any concerted effort to oppose the law. Said one MPS official, the justification for the law is based on "human dignity. If the government wants to forbid [embryo research], we have to accept that."

Steven Dickman

\section{Irvine ordinance}

\section{San Francisco}

EXPRESSING disgust with slow-moving national and international environmental policies - and firmly entrenching itself as a liberal haven in ultra-conservative Orange County - the city of Irvine, California, last week passed a comprehensive ordinance banning the manufacture, sale or distribution of any products containing ozone-depleting compounds (ODCs).

The city calls the local law - which extends to chlorofluorocarbons (CFCs), halon and chemical compounds such as carbon tetrachloride and methyl chloroform often used in cleansing and degreasing solvents - the most comprehensive measure of its kind in the world. "We are really trying to be leaders and set an example for the rest of the nation", says city council aide Katherine Lyon. "The federal and state governments and the international agreements have been too little, too late. If we want to get anything done, we have to start somewhere. . ..."

Irvine is a planned community of 105,000 residents about 50 miles south-east of Los Angeles - and has become home to a variety of electronic, aerospace and other high-technology companies. City officials say the measure, which passed by a 4-1 vote and which will take effect on 1 July 1990 , will affect approximately 10 per cent of Irvine's 5,000 businesses.

Supermarkets will have to remove polystyrene containers made with CFCs. And, although coolants such as freon can be used in air conditioners and refrigeration units until an acceptable alternative is available, repair shops must install equipment to recycle the compounds.

The ordinance provides temporary exemption for businesses having trouble meeting the one-year deadline. Also exempted are university research programmes, and medical and military companies that must employ ODCs to meet government regulations.

The ordinance was opposed by some business-people, who argued that singling out one small community placed an undue economic burden on local employers. But Lyon says the new law has widespread support - and that the city has received many unsolicited letters of approval.

This is not the first innovative and controversial programme instituted under Irvine mayor Larry Agran. About a year ago, the city established a voluntary kerbside recycling programme now used as a model around the country. And Irvine has a comprehensive human-rights ordinance which prohibits discrimination on the basis of race, sex, sexual orientation, religion or ethnic origins.

Such actions stand out in staunchly conservative Orange County - and Lyon says several people have termed Irvine the "Berkeley of the south". Robert Buderi 